\title{
Typing and Antifungal Susceptibility of Candida Spp. Isolated from Clinical Samples
}

\author{
Senay Ozturk Durmaz* \\ Department of Infectious Diseases and Clinical Microbiology, Turkey
}

*Corresponding author: Senay Ozturk Durmaz, Antalya Kepez State Hospital, Department of Infectious Diseases and Clinical Microbiology, Turkey

\begin{tabular}{|c|c|}
\hline ARTICLE INFO & ABSTRACT \\
\hline Received: 㓞 January 30, 2019 & Summary \\
\hline Published: February 13, 2019 & In our study, we aimed to identify 100 yeast species fungus isolated from clinical sam- \\
\hline $\begin{array}{l}\text { Citation: Senay Ozturk Durmaz. Typ- } \\
\text { ing and Antifungal Susceptibility of } \\
\text { Candida Spp. Isolated from Clinical } \\
\text { Samples. Biomed J Sci \& Tech Res } \\
\text { 14(4)-2019. BJSTR. MS.ID.002570. }\end{array}$ & $\begin{array}{l}\text { various antifungals to these species. } 55 \text { of the Candidas were isolated from urine, } 18 \text { from } \\
\text { respiratory tract, } 12 \text { from body fluids, } 11 \text { from blood, and } 4 \text { from other ( } 3 \text { wound } 1 \text { vagi- } \\
\text { nal) samples. } 46 \text { of them were C. albicans, } 19 \text { were } C \text {. glabrata, } 14 \text { were } C \text {. parapsilosis, } 11 \\
\text { were } C \text {. keyfr, } 9 \text { were } C \text {. tropicalis, and } 1 \text { was } C \text {. krusei. C.albicans is still the most common- } \\
\text { ly isolated type of candida. Amphotericin B remains one of the most effective antifungal } \\
\text { agents. There is increased resistance to fluconazole. Increased resistance in all candida } \\
\text { species is an important treatment problem, especially in people with low immune re- } \\
\text { sistance. For this reason, identification of species, antifungal testing and antifungal agent } \\
\text { should be treated carefully. }\end{array}$ \\
\hline
\end{tabular}

Keywords: Candida; Antifungal Susceptibility; Fluconazole Resistance

\section{Introduction}

Candida species are the most common fungal pathogen affecting humans. These organisms have a wide spectrum of disease ranging from noninvasive superficial infections to deep-tissue infections. The frequency of both out-of-hospital and nosocomial candida infections increases, especially due to broad-spectrum antibiotic use, intravascular devices and the population of immunosuppressive patients $[1,2]$. In Candida species, blastoconidia, pseudohyphae, chlamydospore and tube jerm formation, ascospore formation are important in the definition of species. Colonies of Candida species form colonies smelling yeast, with a smooth or wrinkled edge, moist, creamy appearance. They reproduce by means of sexual and asexual spores and are classified based on reproductive patterns [3-5]. In the ranking of nosocomial fungal infections, urinary tract infections are the first and fungemiler is the second. It is known that urinary catheter application increases the fungus [6]. Diabetes mellitus, elevated glucose level increases fungal growth without tissue invasion. Candida colonization in severe burn may develop into tissue invasion. Increased estrogen and vaginal glycogen levels during pregnancy cause vaginal colonization. Hyperalimentation fluids facilitate the intravenous hyperglycemic environment and facilitate candida infections. Intravascular catheters, pressure monitoring devices, prosthetic heart valves, and pacemaker placement may lead to disseminated candidiasis. The suppression of flora bacteria with broad spectrum antibiotics can lead to candida infections [7-9].

\section{Materials and Methods}

One hundred Candida strains isolated from different clinical samples from SSK Izmir Training Hospital Microbiology Laboratory were included in the study. C. albicans ATCC 90028, C. krusei ATCC 6258, C. parapsilosis ATCC 90018 were used as standard strain. Resistance states of the identified candida species to amphotericin B, fluconazole, voriconazole, itraconazole RPMI 1640 (1.5\% agared) medium (ANGUS) and E test strips 7.0 with buffered $\mathrm{pH}$ of MOPS (3-N-morpholinopropanesulfonic acid) and E test strips (AB Biodisk, Solna), Sweeden). Patients with yeast were also evaluated for risk factors. Specimens were planted in Sabouraud's Dextrose 
Agar (SDA) for primary isolation. From the cultures that were understood to be pure, passages were made to the slanted SDA tubes for use in the advanced stage of the identification. Yeasts were added in $0.5 \mathrm{ml}$ human serum to a small portion of the colony to be tested and mixed. It was incubated at $37^{\circ} \mathrm{C}$ for $2.5-3$ hours. The specimens were examined by microscope at +40 magnification and the flament shaped structures were evaluated as germ tube. The germ-producing yeast strains were defined as C. albicans [10-12].

\section{Results}

Of the 100 species of yeasts identified from the samples, 55 were isolated from urine, 12 from various body fluids, 18 from respiratory tract, 11 from blood and 4 from other specimens ( 3 from wound, 1 from vagina). 46 of the yeast species were named C. albicans, 19 were C. glabrata, 14 were $C$. parapsilosis, 11 were $C$. keyfr, 9 were $C$. tropicalis and 1 were $C$. krusei (Table 1). Germ tube test was found to be positive (100\%) in all yeasts that were typed as $C$. albicans. In 90 of 100 licensed yeasts, sensitivity tests were tested by $\mathrm{E}$ test method. The distribution of abstracted fungi according to predisposing factors; $4 \%$ had diabetes + catheters, $6 \%$ had fluconazole use, $17 \%$ had antibiotic use + had an underlying disease, urinary catheter or any catheter and received immunosuppressive treatment. In urine samples, fluconazole $41 \%$, fluconazole $47 \%$, and voriconazole resistance $75 \%$ were found in C. albicans. $34 \%$ fluconazole, $47 \%$ itraconazole and $6 \%$ voriconazole resistance were found in the Candidias detected in urine except C. albicans. Fluconazole was isolated in $52 \%$ of the C. albicans isolated from the urine samples and itraconazole resistance was found in $30 \%$ and voriconazole resistance was $73 \%$. In the non-C. albicans yeasts isolated from the urine samples, $22 \%$ fluconazole and 33\% itraconazole and 5\% voriconazole resistance were found. Amphotericin B resistance was not detected in any of the cases (Table 2).

Table 1: Distribution of candidias according to their location.

\begin{tabular}{|c|c|c|c|c|c|}
\hline \multicolumn{7}{|c|}{ Distribution of Candidias According to their Location } \\
\hline Species & Urine (n: 55) & Respiratory Tracts (n: 18) & Body Fluids (n: 12) & Blood (n: 11) & 0ther (n: 4) \\
\hline C.albicans & 21 & 11 & 5 & 6 & 0 \\
\hline C. glabrata & 15 & 2 & 2 & 3 & 0 \\
\hline C.tropicalis & 6 & 0 & 3 & 0 & 0 \\
\hline C.parapsilosis & 5 & 3 & 2 & 0 & 0 \\
\hline C.keyfr & 8 & 1 & 0 & 11 & 0 \\
\hline C. krusei & 0 & 1 & 12 & & 0 \\
\hline Toplam & 55 & 18 & & \\
\hline
\end{tabular}

Table 2: Candida species and resistance distributions according to samples.

\begin{tabular}{|c|c|c|c|}
\hline & \multicolumn{2}{|c|}{ Candida Species and Resistance Distributions According to Samples } \\
\hline Albicans-Non Albicans & Fluconazole & Itraconazole & Voriconazole \\
\hline C.albicans (n: 40) & & & $12(\% 75)$ \\
\hline Urine: 17 & $7(\% 41)$ & $7(\% 47)$ & $17(\% 73)$ \\
\hline Other than urine (n: 23) & $12(\% 52)$ & $7(\% 30)$ & \\
\hline Other than C. albicans (n: 50) & & & $1 \%(\% 47)$ \\
\hline Urine: 32 & $11(\% 34)$ & $6(\% 33)$ & $1(\% 5)$ \\
\hline Other than urine (n: 18$)$ & $4(\% 22)$ & & \\
\hline
\end{tabular}

\section{Discussion}

Nosocomial candida infections are an important cause of morbidity and mortality in immunocompromised patients. Candida species are isolated from $15 \%$ of nosocomial infections, $86 \%$ of all nosocomial fungal infections and $8-10 \%$ of nosocomial blood circulatory infections. In a study of candida cases in urine; $60.8 \%$ C. albicans, $12.5 \%$ C. glabrata, $11.2 \%$ C.topicalis, $6 \%$ C. parapsilosis isolated (6).In our study, 38\% of the 55 cannabis detected in urine were C.albicans, 27\% C.glabrata, 15\% C.keyfr, 10\% C. topicalis and $10 \%$ u. C. albicans and C. glabrata. It was reported that C. glabrata and C. parapsilosis fungemias increased 4-6 times in Taiwan in 1981-1993 related to candidiasis. According to the results of one year study of 8 European countries; C. albicans were shown to be isolated in 55\%, C. glabrata in 20\%, C. kruzei in $0-20 \%(10,11)$. In our study, $54.5 \%$ C. albicans, $27 \%$ C. topicalis and $18 \%$ C. glabrata were found in candidemia and the results were similar. In 46 of 40 C.albicans cases, susceptibility to E test was evaluated and resistance to voriconazole was found in 16 (40\%), itraconazole in $12(30 \%)$ and voriconazole in 29 (70\%).

Of the total of 90 strains, 28 (31\%) were resistant to fluconazole and 22 (24\%) to itraconazole and 32 (35\%) were resistant to voriconazole, while no resistance to amphotericin $\mathrm{B}$ was detected. Yilmaz et al. [13] described the candelas isolated from various clinical specimens using API CAUX system and 
conventional methods and studied the antifungal sensitivity E test method; They found 44\% itraconazole, $42 \%$ flucanozol and $2 \%$ amphotericin B resistance. Degerli et al. [14] have performed the antifungal sensitivity of 60 strains, including 38 C. albicans and 22 nonalbicans, by E test method. In this study, C. albicans was reported to be resistant to 34\% fluconazole, 32\% itraconazole, 3\% amphotericin. Zer et al. [15] described 115 (56\%) of 205 candida strains as $C$. albicans with API and found $23 \%$ of $C$. albicans with E test and $27 \%$ of all Candida isolates in the study found resistant to fluconazole.

\section{Conclusion}

In our study, the most common type of candida was $C$. albicans. In addition, five different species were identified except $C$. albicans. This is a sign of infections that may occur with other candida species other than C. albicans, especially C. glabrata in the future. The determined fluconazole resistance demonstrates the need for more detailed studies to be conducted in clinical-laboratory cooperation in order to be more careful in the use of this agent and to determine the in vivo response.

\section{References}

1. Warren NG, Hazen KC (1999) Candida, Cryptococcus and Other Yeast of Medical importance. In: Murray PR, Baron EJ, Pfaller MA, Tenover FC, Yolken RH (Eds.), Mauel of clinical Microbiology. American Society for Microbiology, Washington DC, USA, pp. 1184-1199.

2. Maenza JR, Merz WG (1998) Candida albicans and related species. In: Gorbach SL,Batlett JG, Blacklow NR(eds), Infectious Diseases WB, Saunders Company, Philadelphia, USA, pp. 2313-2322.

3. Koneman EW, Allen SD, Janda WM (1977) Mycology Color Atlas and Textbook of Diagnostic Microbiology ( $5^{\text {th }}$ edn.), Lippincott Co, Phidelphia, USA, pp. 983-1069.

\section{ISSN: 2574-1241}

DOI: 10.26717.BJSTR.2019.14.002570

Senay Ozturk Durmaz. Biomed J Sci \& Tech Res

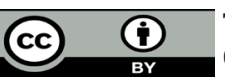

This work is licensed under Creative Commons Attribution 4.0 License

Submission Link: https://biomedres.us/submit-manuscript.php
4. Warren NG, Shadomy HJ (1995) Candida, cryptococcus and other yeast of medical importance. In: Murray PR, Baron EJ, Phaller MA, Tenover FC, Yolken RH (Eds). Manuel of Clinical Microbiology ( $6^{\text {th }}$ edn.), , ASM press, Washington DC, USA, pp. 723-737.

5. Dixon DM, Rhodes JC, Framtling RA (1999) Toxonomy, Classification or Morphology of the fungi. In: Murray PR, Baron EJ, Phaller MA, Tenover FC, Yolken RH (Eds.), Manuel of Clinical Mikrobiology. American Society for Microbiology, Washington DC, USA, pp. 1161-1166.

6. Kiraz N, Akgün Y (2000) The distribution of Candida spp. Cousing urinary tract infections, Mycosis pp. 43-237.

7. John E, Edwards JR (1995) Candida species. In: Mandell GL, Bennett JE, Dolin R (Eds.), ( $4^{\text {th }}$ edn.), Principles and practise of infectious disease. Churchill Livingstone, New York, USA, pp. 2289-2306.

8. Erbakan N (1989) Fungal diseases of the skin. Publisher Clinics Turkey, Ankara, Turkey, p. 1-90.

9. Kaufman R (1988) Establishing a correct diagnosis of vulvovaginal infection. Am J Obstet Gynecol 158(4): 986-988.

10. Grillot R (1992) Epidemiological survey on candidemia in Europe, mycology newsletter 2: 11-13.

11. Yhu chening H, Tzou Yien L, Rey-in I, Yı Hong C (1999) Cadidemia in special care nurseries: Comparison of albicans and parapsilosis infection trends in invasive fungal infections 5. Abstract book 153: 14-16.

12. Helvacı S, Gedikoğlu S, Mıstık R (1992) Germ tube test for diagnosis of candida albicans. Infec Derg 6: 141-143.

13. B Yılmaz, A Botrel, S Gençer, S Özer Çeşitli klnink örneklerden (2002) Isolation of isolated candida strains and detection of amphotericin $\mathrm{B}$, fluconazole and itraconazole sensitivities by $\mathrm{E}$ test. XXX. Türk Mikrobiyoloji kongresi,30 eylül-05 ekim 2002 Antalya Başak matbaacılık pp. 313.

14. S Sürücüoğlu, K Değerli, S Kuzutepe, Ö Tünger, E Aktaş, B Özbakkaloğlu (2002) Examination of antifungal resistance in candida isolates which are the causative agents of invasive infection XXX. Türk Microbiology Congress 30 September-05 October 2002 Antalya Başak, pp. 314.

15. Yasemin Zer (2002) The identification and antifungal susceptibility of the candida strains isolated from patients in the Iclal intensive care unit Turkish Journal of Microbiology 32: 230-234.

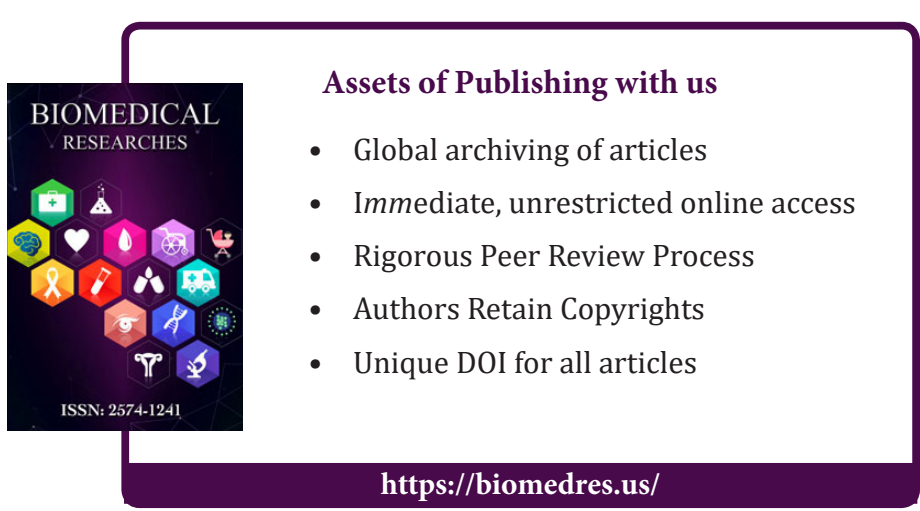

